\title{
Effects of indoor environment and lifestyle on respiratory health of children in Chongqing, China
}

\author{
Wenyan Li ${ }^{1}$, Qin Liu ${ }^{1}$, Yiwen Chen ${ }^{1}$, Bo Yang ${ }^{1}$, Xin Huang ${ }^{1}$, Yueyue Li ${ }^{1}$, Junfeng Jim Zhang ${ }^{2,3,4}$ \\ ${ }^{1}$ School of Public Health and Management, Research Center for Medicine and Social Development, Collaborative Innovation Center of Social Risks \\ Governance in Health, Chongqing Medical University, Chongqing 400016, China; ${ }^{2}$ Nicholas School of the Environment and Duke Global Health \\ Institute, Duke University, Durham, NC, USA; ${ }^{3}$ Duke Kunshan University, Kunshan 215316, China; ${ }^{4}$ Guangzhou Institute of Respiratory Health, \\ The First Affiliated Hospital of Guangzhou Medical University, Guangzhou 510120, China \\ Contributions: (I) Conception and design: Q Liu, W Li, JJ Zhang; (II) Administrative support: Q Liu; (III) Provision of study materials or patients: Q \\ Liu, JJ Zhang; (IV) Collection and assembly of data: Q Liu, W Li, Y Chen, B Yang, X Huang, Y Li; (V) Data analysis and interpretation: Q Liu, W \\ Li; (VI) Manuscript writing: All authors; (VII) Final approval of manuscript: All authors. \\ Correspondence to: Qin Liu. School of Public Health and Management, Research Center for Medicine and Social Development, Collaborative \\ Innovation Center of Social Risks Governance in Health, Chongqing Medical University, Chongqing 400016, China. Email: liuqin81622@163.com.
}

Background: The prevalence of certain respiratory diseases of children in China appears to be on the rise in recent decades. This study aims to explore residential environmental factors that may affect respiratory diseases and lung function of children and to assess the effects of lifestyle (diet and exercise) on lung function. Methods: The study was conducted in Chongqing, southwest of China in June, 2017. Information on respiratory diseases was obtained from 2,126 primary school children through a family questionnaire by purposive sampling. In addition, a random sample of 771 children participating in the family-questionnaire was selected for physical measurements and lung function test as well as lifestyle questionnaire survey. Chi-square test and multivariate logistic regressions were used to analyze the relationship between indoor environment and children's respiratory diseases. The effects of indoor environment and lifestyle on lung function indices were analyzed by t-test, variance analysis, and univariate and multivariate linear regression methods.

Results: Among residential environmental factors, indoor ventilation and air circulation were significant associated with children's respiratory health outcomes. The use of air conditioning for more than 8 h/day in summer was a risk factor for asthma with an adjusted odds ratio (AOR) of 1.99, bronchitis (AOR =1.62), and allergic rhinitis (AOR =1.51). Ventilation for less than $12 \mathrm{~h}$ per day during summer increased the risk for allergic rhinitis (AOR =1.40). Children living in homes with an opened kitchen had the risk of developing allergic rhinitis 1.51 times higher than children living in homes with a closed kitchen. Indoor dampness and mold were significantly associated with increased risks for childhood asthma (AOR =2.16), bronchitis $(\mathrm{AOR}=1.55)$ and allergic rhinitis $(\mathrm{AOR}=1.55)$. The frequent use of hygienic incense and mosquito coils also increased the risk for asthma (AOR =2.58) and bronchitis ( $A O R=1.42$ ) in children. The multiple linear regression results showed that frequent use of air fresheners reduced children's peak expiratory flow (PEF) and small airway function $\left(\mathrm{FEF}_{25-75}\right)$ after potential influencing factors were adjusted for. Analyses of lifestyle variables showed that increased lung function $\left(\mathrm{FVC}, \mathrm{FEV}_{1}, \mathrm{FEV}_{3}\right.$ ) was associated with increasing consumption of vegetable and fruit as well as increasing time of physical exercise.

Conclusions: This study identified the following residential risk factors for children's respiratory diseases in Chongqing: poor indoor ventilation, home dampness and mold presence, and frequent use of hygienic incense and mosquito coils. Frequent use of air fresheners is associated with reduced lung function in children. High frequency consumption of vegetables, fruits and dairy products as well as daily exercise for more than 1 hour have positive effects on children's lung development.

Keywords: Indoor environment; diet; exercise; respiratory disease; lung function 
Submitted Oct 08, 2019. Accepted for publication Mar 19, 2020.

doi: $10.21037 /$ jtd.2020.03.102

View this article at: http://dx.doi.org/10.21037/jtd.2020.03.102

\section{Introduction}

Respiratory diseases are one of the most common diseases in children. Taking asthma as an example, in 2010-2012, a study conducted in 10 cities, named China-ChildrenHomes-Health $(\mathrm{CCHH})$, showed the prevalence of asthma ranged from $1.7 \%$ to $9.8 \%$ (mean $6.8 \%$ ) in children (1). In addition, incidence rates of bronchitis and allergic rhinitis have also been on the rise in China. A number of factors contribute to children's respiratory diseases, including heredity, early life exposure, external environment, lifestyle, psychological stress and others. Recently, A growing number of researchers in US (2), Japan (3), New Zealand (4) and Romania (5) and Portugal (6), etc., were turning their eyes to indoor environment where children spent the vast majority of their time. The World Health Organization (WHO) considers indoor air pollution as one of the top 10 threats to human health. According to an WHO report, 100 thousand people die of asthma every year due to indoor air pollution around the world, of which $35 \%$ are children. Children are vulnerable to respiratory diseases because their lungs and immunity system have not yet fully developed (7). In China, studies on indoor environment and child respiratory health started lately, while also has attracted increasing attention recently. The impact of indoor environment on children's respiratory health might be different due to the differences in race, climate, architectural features, life habits and social environment. The site of this study-Chongqing, is located in southwest China, and it has a subtropical monsoon climate, known for its foggy mountainous terrain, with an annual average relative humidity of $70-80 \%$.

The acceleration of modernization and urbanization process has not only brought about changes of indoor environment, but also the changes in living habits, diet, and physical activity. These lifestyle changes may have important effects on children's respiratory health and lung development. Based on the results of the physical exams of students in China, lung vital capacity [e.g., forced vital capacity (FVC)] of students has shown a declining trend over the past 30 years (8) as the vital capacity is an important indicator reflecting lung function of students. In terms of diet, vegetables and fruits are rich sources of vitamins, minerals, dietary fiber and other nutrients, with antioxidant, antibacterial, and antiviral effects, which help the lung to resist immune damage (9). Studies have shown that intakes of vegetables and fruits were closely related to respiratory health, which can reduce the incidence of respiratory symptoms and diseases and improve the lung function of children $(10,11)$. Physical exercises have proven to enhance muscle strength, improve cardiopulmonary strength, avoid obesity, etc. However, little is known about the impact on lung function and most previous studies have been conducted in adults or athletes mostly $(12,13)$.

Considering the aforementioned factors, we conducted this study to identify which factors affect children's respiratory health in the family indoor environment. In addition, the objective indicators of lung function were used to analyze the effects of indoor environment, diet and exercise on children's respiratory system.

\section{Methods}

\section{Subjects and design}

This cross-sectional study was carried out in Chongqing, China in June 2017. A total of 2,397 students in grades one to six from two primary schools in two districts were recruited. The distance between the two districts, the air quality and the compatibility of the schools were the factors to be considered in the school selection. After informed consent was obtained from both participating children and their parents or guardians, 2,126 children aged 6-13, of whom $51.4 \%$ were male and $48.6 \%$ were female, were finally enrolled in the study.

Of the 2,126 children participating in the questionnaire survey, 771 children in grades 2 to 5 were randomly selected by gender and age for lung function tests (grade 1 students were too young to carry out the lung function test and grade 6 students gave up the test for the academic pressure). See Figure 1 for the flow chart of study subjects selection and content. The study protocol was approved by the Chongqing Medical University Ethics Committee and Duke Kunshan University IRB, respectively.

\section{Family questionnaire survey}

The family questionnaire, based on the American 


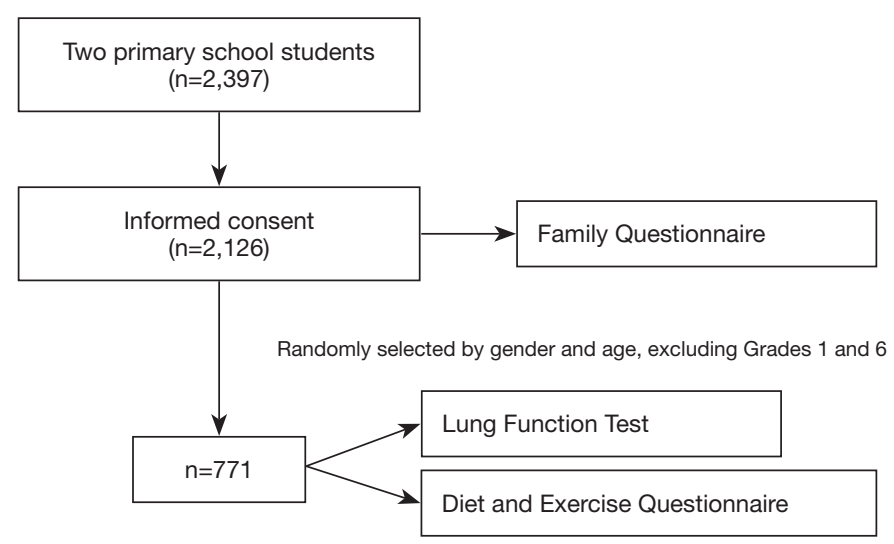

Figure 1 Flow chart of this cross-sectional survey.

Epidemiological Standards Questionnaire (ATS-DLD78-C) (14,15), was translated into Chinese and made minor changes to suit for Chinese parents or guardians to fill out. It had four sections of questions about potential risk factors for children's respiratory health. The first section collected indoor environment factors including perperson living area, type of fuel used for cooking, kitchen ventilation devices, environmental tobacco smoke (ETS), renovation, dampness and mold, use of air purifiers, air fresheners, hygienic incense and mosquito coils, indoor ventilation and duration. The second section sought family history: whether parents had doctor-diagnosed asthma and bronchitis. The third section focused on early life factors: duration of exclusive breastfeeding, birth weight, premature birth. The last section asked questions about children's respiratory health histories, including doctor-diagnosed asthma, bronchitis and allergic rhinitis. In addition to the above four sections, socioeconomic factors, such as parental education level were also included in the questionnaire.

\section{Lung function test and life-style questionnaire}

Lung function was measured using the Spirolab III lung function instrument and followed the American Thoracic Society's standard spirometry procedure. The procedure required each child to perform at least three FVC trials that were acceptable in overall shape, and with at least two acceptable trials that were reproducible. Before testing, height and weight were measured for each child. Each child repeated the test at least 3 times until the instrument displayed a repeatable FVC value. The data were automatically converted into the standard state by the instrument and then selected the best value for recording.
Spirometry measures used in our analysis include FVC, forced expiratory volume in the first second $\left(\mathrm{FEV}_{1}\right)$, peak expiratory flow (PEF), forced expiratory flow between $25 \%$ and $75 \%$ of $\mathrm{FVC}\left(\mathrm{FEF}_{25-75}\right)$, forced expiratory volume the in 3 seconds $\left(\mathrm{FEV}_{3}\right)$. Students who took part in the lung function test were also asked about the frequencies of eating vegetables, fruits and dairy products, the frequency and duration of physical exercise through a life-style questionnaire.

\section{Statistical analysis}

All statistical analysis was performed with SPSS version 21.0. For the whole group of respiratory diseases, Chisquare test and multivariate logistic regression analysis were conducted for the association between indoor environment factors and children's respiratory diseases. For the lung function test subgroup, the effects of indoor environment and lifestyle on lung function $\mathrm{FVC}, \mathrm{FEV}_{1}, \mathrm{PEF}, \mathrm{FEF}_{25-75}$ and $\mathrm{FEV}_{3}$ values were analyzed by $t$-test, ANOVA, univariate and multivariate linear regression methods.

\section{Results}

\section{Health conditions and social-economic status}

Of the 2,126 respondents, the average age was $9.38 \pm 1.60 \mathrm{y}$. Among them, 76 (3.6\%), 500 (23.5\%) and 281 (13.2\%) children were reported to have had doctors-diagnosed asthma, bronchitis and allergic rhinitis, respectively. In terms of parental education level, the parents in our study were generally not highly educated and we found the higher the parents' education level, the higher the proportion 
of children with asthma, bronchitis and allergic rhinitis $(\mathrm{P}<0.05)$. Children whose parents had asthma were also more likely to have asthma, as was the case with bronchitis $(\mathrm{P}<0.05)$. No association was observed between parental respiratory diseases and allergic rhinitis in children. In terms of early life factors, preterm infants accounted for $7.3 \%$ and low birth weight infants accounted for $3.3 \%$ of children; $17.2 \%$ of children had never been exclusively breastfed, while $14.8 \%$ of children were exclusively breasted for less than 4 months. Children born prematurely have a higher proportion of asthma and bronchitis than normal $(\mathrm{P}<0.05)$. The duration of exclusive breastfeeding also played an important role in the development of bronchitis and allergic rhinitis $(\mathrm{P}<0.05)$. The effect of low birth weight on these three respiratory diseases were not observed. See Table 1 for details.

Table 1 Chi-square test results between other factors and respiratory diseases in children

\begin{tabular}{|c|c|c|c|c|}
\hline Variables & Total number $(\mathrm{n}, \%)$ & Asthma (n, \%) & Bronchitis (n, \%) & Allergic rhinitis $(n, \%)$ \\
\hline \multicolumn{5}{|l|}{ Mother's education level } \\
\hline Junior high school and below & $905(42.6)$ & $20(2.2)$ & $150(16.6)$ & $79(8.7)$ \\
\hline High school & $737(34.7)$ & $29(3.9)$ & $197(26.7)$ & $112(15.2)$ \\
\hline College and above & $484(22.8)$ & $27(5.6)$ & $153(31.6)$ & $90(18.6)$ \\
\hline$\chi^{2}$ & & 10.805 & 46.110 & 30.613 \\
\hline$P$ & & 0.005 & 0.000 & 0.000 \\
\hline \multicolumn{5}{|l|}{ Father's education level } \\
\hline Junior high school and below & $869(40.9)$ & $18(2.1)$ & $154(17.7)$ & $83(9.6)$ \\
\hline High school & $761(35.8)$ & $33(4.3)$ & $193(25.4)$ & $103(13.5)$ \\
\hline College and above & $496(23.3)$ & $25(5.0)$ & $153(30.8)$ & 95 (19.2) \\
\hline$x^{2}$ & & 10.070 & 32.481 & 25.486 \\
\hline$P$ & & 0.007 & 0.000 & 0.000 \\
\hline \multicolumn{5}{|l|}{ Mother suffered from asthma } \\
\hline Yes & $25(1.2)$ & $5(20.0)$ & $8(32.0)$ & $3(12.0)$ \\
\hline No & 2,101 (98.8) & $71(3.4)$ & $492(23.4)$ & $278(13.2)$ \\
\hline$x^{2}$ & & 19.800 & 1.012 & 0.033 \\
\hline$P$ & & 0.000 & 0.314 & 0.857 \\
\hline \multicolumn{5}{|l|}{ Mother suffered from bronchitis } \\
\hline Yes & $80(3.8)$ & $5(6.3)$ & $48(60.0)$ & $16(20.0)$ \\
\hline No & 2,046 (96.2) & $71(3.5)$ & $452(22.1)$ & $265(13.0)$ \\
\hline$x^{2}$ & & 1.726 & 61.508 & 3.334 \\
\hline$P$ & & 0.189 & 0.000 & 0.068 \\
\hline \multicolumn{5}{|l|}{ Father suffered from asthma } \\
\hline Yes & $22(1.0)$ & $9(40.9)$ & $9(40.9)$ & $5(22.7)$ \\
\hline No & 2,104 (99.0) & $67(3.2)$ & $491(23.3)$ & $276(13.1)$ \\
\hline$\chi^{2}$ & & 89.891 & 3.738 & 1.753 \\
\hline $\mathrm{P}$ & & 0.000 & 0.053 & 0.186 \\
\hline
\end{tabular}

Table 1 (continued) 
Table 1 (continued)

\begin{tabular}{|c|c|c|c|c|}
\hline Variables & Total number (n, \%) & Asthma (n, \%) & Bronchitis (n, \%) & Allergic rhinitis $(n, \%)$ \\
\hline Yes & $95(4.5)$ & $5(5.3)$ & $61(64.2)$ & $9(9.5)$ \\
\hline No & 2,031 (95.5) & $71(3.5)$ & $439(21.6)$ & $272(13.4)$ \\
\hline$\chi^{2}$ & & 0.822 & 91.545 & 1.215 \\
\hline \multicolumn{5}{|l|}{ Preterm birth } \\
\hline Yes & $156(7.3)$ & $11(7.1)$ & $51(32.7)$ & $20(12.8)$ \\
\hline No & $1,970(92.7)$ & $65(3.3)$ & $449(22.8)$ & $261(13.2)$ \\
\hline$\chi^{2}$ & & 5.903 & 7.877 & 0.023 \\
\hline Yes & $70(3.3)$ & $2(2.9)$ & $11(15.7)$ & $7(10.0)$ \\
\hline No & $2,035(96.7)$ & $73(3.6)$ & 486 (23.9) & $270(13.3)$ \\
\hline$\chi^{2}$ & & 0.105 & 2.503 & 0.632 \\
\hline $\mathrm{P}$ & & 0.746 & 0.114 & 0.426 \\
\hline \multicolumn{5}{|c|}{ Exclusive breastfeeding duration } \\
\hline None & $366(17.2)$ & $16(4.4)$ & $93(25.4)$ & $55(15.0)$ \\
\hline$<4$ months & $315(14.8)$ & $13(4.1)$ & $88(27.9)$ & $66(21.0)$ \\
\hline 4-6 months & $599(28.2)$ & $21(3.5)$ & $157(26.2)$ & $74(12.4)$ \\
\hline
\end{tabular}

\section{Housing characteristic in target house}

House characteristic of all participants were shown in Table 2. More than half $(52.9 \%)$ of the students were exposed to ETS at home. The number of coal-burning households only accounted for $0.9 \%$ of the households. Most kitchens (86.1\%) had mechanical ventilation devices such as range hoods or exhaust fans. Uncommon use of air purifiers (3.7\%) was reported; $15.8 \%$ of households have pets; dampness and mold were present in $8.1 \%$ of the families, including mildew spot and mildew smell. About $15 \%$ of the families used hygienic incense and mosquito coils and air fresheners frequently. More than half of the families used air conditioning for more than $8 \mathrm{~h} /$ day in summer. Finally, more than half $(65.3 \%)$ of the children had their own separated bedrooms.

\section{Indoor environment and respiratory diseases}

As shown in Table 2, living higher than 4 floors, dampness and mold, frequent use of hygienic incense and mosquito coils, and using air conditioning for more than $8 \mathrm{~h} /$ day in summer were each associated with a higher incidence of asthma $(\mathrm{P}<0.05)$. For bronchitis, the risk factors included living area per person, opened kitchen type, dampness and mold, frequent use of hygienic incense and mosquito coils, rare use of air fresheners, and air conditioning use for more than $8 \mathrm{~h} /$ day $(\mathrm{P}<0.05)$. We also found living area per person, opened kitchen type, mechanical ventilation in kitchen, dampness and mold, rare use of air fresheners, ventilation duration in summer $<12 \mathrm{~h} /$ day, and use of air conditioning for more than $8 \mathrm{~h} /$ day were positively associated with allergic rhinitis. No association was found between pet 
Table 2 Chi-square test results between indoor environment and childhood respiratory diseases (n, \%)

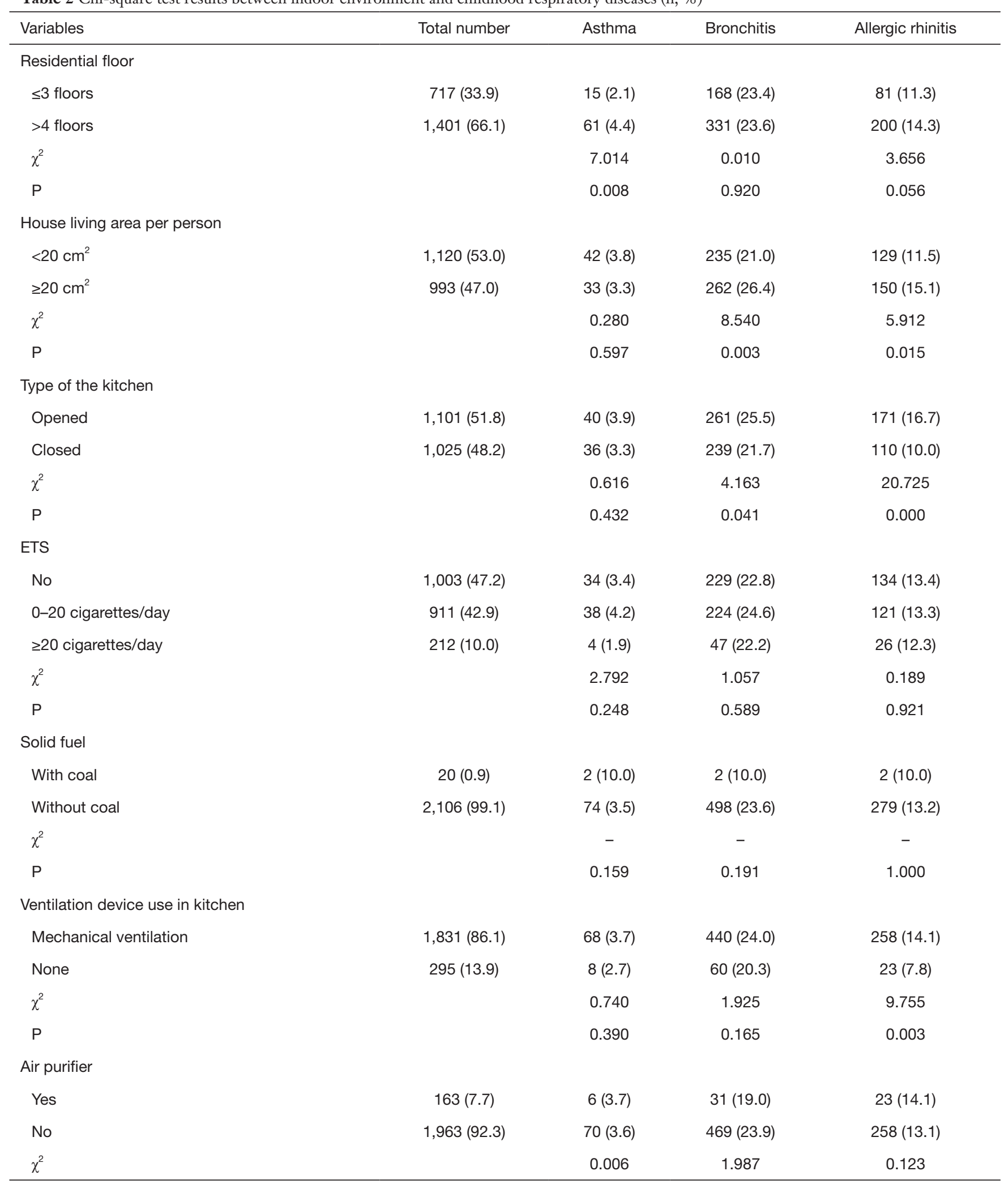

Table 2 (continued) 
Table 2 (continued)

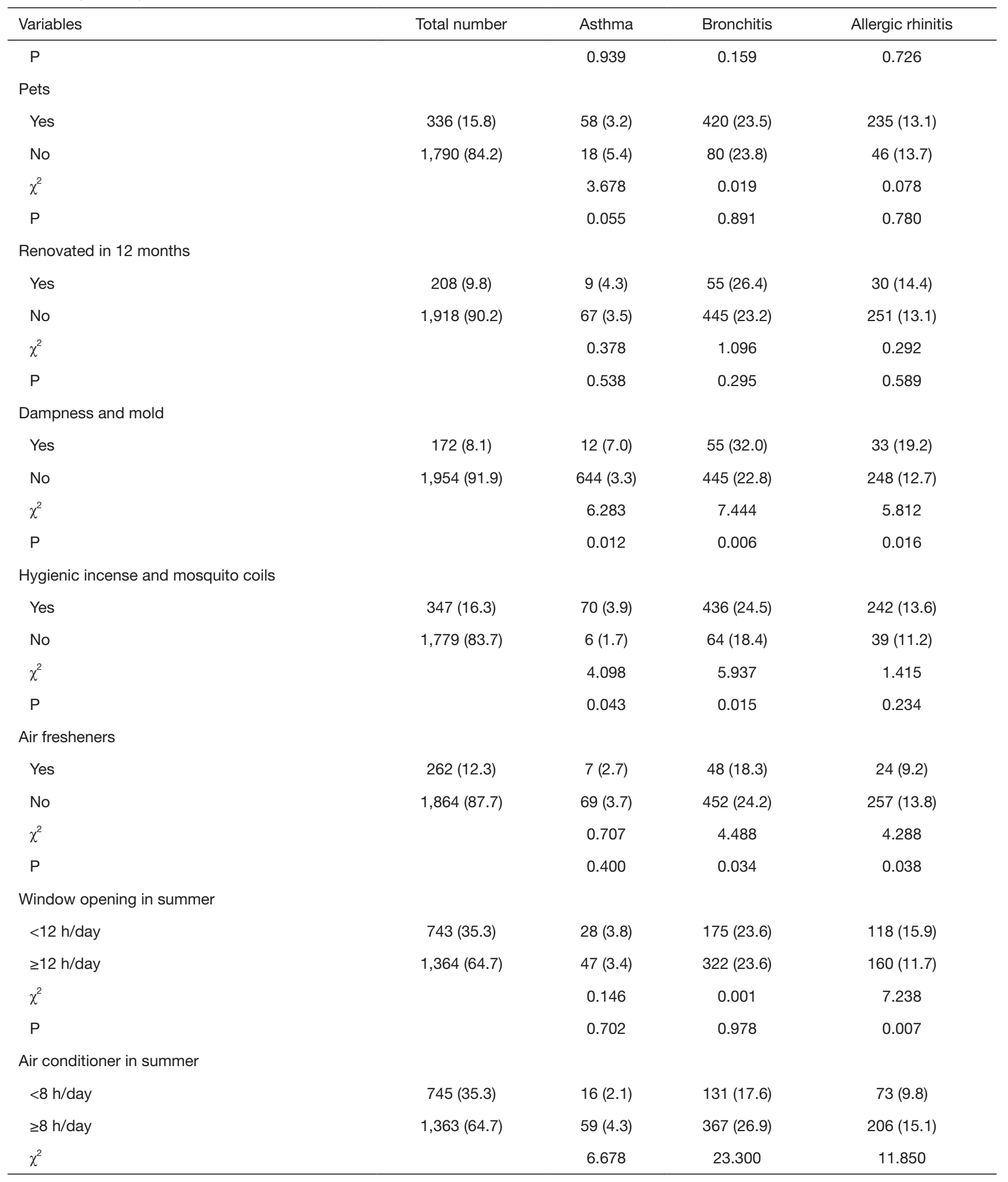

Table 2 (continued) 
Table 2 (continued)

\begin{tabular}{|c|c|c|c|c|}
\hline Variables & Total number & Asthma & Bronchitis & Allergic rhinitis \\
\hline \multicolumn{5}{|c|}{ Window opening in winter } \\
\hline$<8 \mathrm{~h} /$ day & $865(41.0)$ & $28(3.2)$ & $198(22.9)$ & $128(14.8)$ \\
\hline$\geq 8$ h/day & $1,243(59.0)$ & $47(3.8)$ & $300(24.1)$ & $151(12.1)$ \\
\hline$P$ & & 0.507 & 0.508 & 0.077 \\
\hline \multicolumn{5}{|c|}{ Sleep in separate bed } \\
\hline Yes & $1,389(65.3)$ & $50(3.6)$ & $310(22.3)$ & $172(12.3)$ \\
\hline No & $737(34.7)$ & $26(3.5)$ & $190(25.8)$ & $109(14.8)$ \\
\hline
\end{tabular}

keeping, EST, air purifier, or decoration and respiratory diseases.

Based on the results of previous studies, the following covariates were adjusted for in our multivariate logistic regression models, including age, gender, preterm birth, low birth weight, duration of exclusive breastfeeding, parents' education, and parental respiratory disease. As shown in Table 3, the use of air conditioning for more than 8 hours/day, indoor dampness and mold were associated with high risk of developing asthma [adjusted odds ratio $\left.(\mathrm{AOR})^{1}=1.99 ; \mathrm{AOR}^{2}=2.16\right]$, bronchitis $\left(\mathrm{AOR}^{1}=1.62, \mathrm{AOR}^{2}\right.$ $=1.55)$ and allergic rhinitis $\left(\mathrm{AOR}^{1}=1.51, \mathrm{AOR}^{2}=1.55\right)$. The frequent use of hygienic incense and mosquito coils increased the risk of asthma and bronchitis in children by 2.58 times and 1.42 times $(\mathrm{P}<0.05)$. Compared with closed kitchen households, opened kitchen families had 1.51 times greater risk of developing allergic rhinitis in the children. In addition, less than 12 hours of ventilation per day in summer was significantly associated with increased prevalence of allergic rhinitis (AOR $=1.39$ ).

\section{Results on lung function test $(n=771)$}

Table 4 showed the results from the lung function test for healthy children (without any reporting doctor-diagnosed respiratory diseases) of all ages. Table 5 showed that lung function was closely related to children's height and weight $(\mathrm{P}<0.05)$. The significant effects of preterm birth, low birth weight and duration of exclusive breastfeeding on lung function were not observed. The PEF and $\mathrm{FEF}_{25-75}$ in children with respiratory diseases (asthma or bronchitis or allergic rhinitis) were lower than those without any respiratory diseases $(\mathrm{P}<0.05)$. In addition, the 771 children randomly selected from 2,126 children were significantly younger compared with 2,126 and had a lower prevalence of asthma and bronchitis. Among the factors of indoor environment, the number of households that used frequently hygienic incense and mosquito coils in summer was higher than in 2,126 children $(\mathrm{P}<0.05$, data not shown).

\section{Indoor environment and lung function $(n=771)$}

There were significant correlations between lung function and living area per capita, pet keeping, frequent use of air fresheners and sleeping alone by $t$-test and ANOVA. After adjusting for gender, age, height, respiratory diseases, preterm birth, low birth weight and parental education level, variables with $\mathrm{P}<0.1$ in the previous univariate analysis were included in the adjustment model. We found that children living in homes where air fresheners

\footnotetext{
${ }^{1}$, the use of air conditioning for more than 8 hours/day;

${ }^{2}$, the use of air conditioning for indoor dampness and mold.
} 
Table 3 Multi-factor analysis of the influence of home indoor environment on children's respiratory diseases

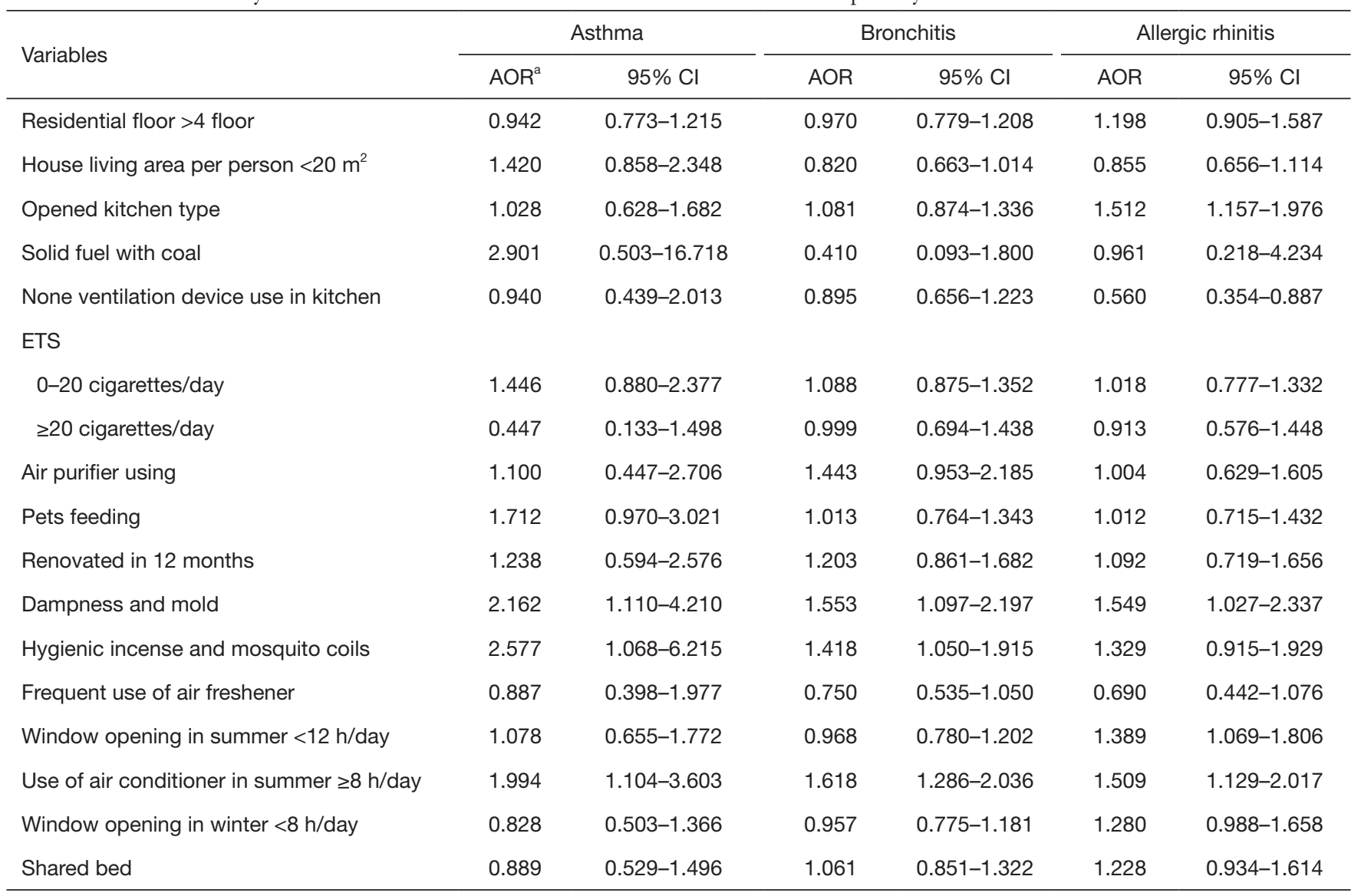

${ }^{a}$, adjusted for age, sex, preterm birth, low birth weight, duration of exclusive breastfeeding, parental education level, whether the parents had asthma or bronchitis. AOR, adjusted odds ratio; ETS, environmental tobacco smoke.

Table 4 Test results of lung function for healthy children of different ages $(\bar{x} \pm s)$

\begin{tabular}{|c|c|c|c|c|c|c|c|}
\hline Indices & \multicolumn{7}{|c|}{ Age group (years) } \\
\hline FVC (L) & $1.64 \pm 0.32$ & $1.73 \pm 0.28$ & $1.89 \pm 0.35$ & $2.18 \pm 0.41$ & $2.31 \pm 0.50$ & 41.305 & 0.000 \\
\hline $\mathrm{FEV}_{1}(\mathrm{~L})$ & $1.53 \pm 0.27$ & $1.59 \pm 0.26$ & $1.75 \pm 0.30$ & $2.01 \pm 0.36$ & $2.14 \pm 0.42$ & 47.891 & 0.000 \\
\hline PEF (L/s) & $3.00 \pm 0.63$ & $3.17 \pm 0.72$ & $3.56 \pm 0.73$ & $3.93 \pm 0.76$ & $4.28 \pm 0.96$ & 31.999 & 0.000 \\
\hline $\mathrm{FEV}_{3}(\mathrm{~L})$ & $1.63 \pm 0.31$ & $1.73 \pm 0.28$ & $1.89 \pm 0.35$ & $2.18 \pm 0.41$ & $2.31 \pm 0.50$ & 42.047 & 0.000 \\
\hline
\end{tabular}

FVC, forced vital capacity; $\mathrm{FEV}_{1}$, forced expiratory volume in the first second; PEF, peak expiratory flow. 
Table 5 Correlation between basic characteristics and lung function in children

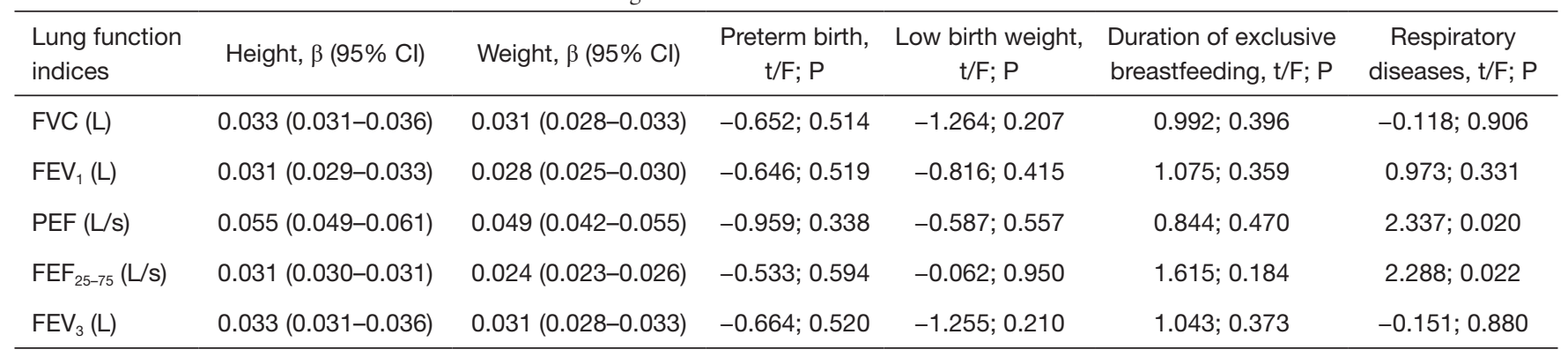

FVC, forced vital capacity; $\mathrm{FEV}_{1}$, forced expiratory volume in the first second; PEF, peak expiratory flow.

Table 6 Multivariate linear regression of relationship between indoor environmental factors and lung function

\begin{tabular}{|c|c|c|c|c|c|c|c|c|c|c|}
\hline Variables & \multicolumn{2}{|c|}{ FVC (L) } & \multicolumn{2}{|c|}{$\mathrm{FEV}_{1}(\mathrm{~L})$} & \multicolumn{2}{|c|}{ PEF (L/s) } & \multicolumn{2}{|c|}{$\mathrm{FEF}_{25-75}(\mathrm{~L} / \mathrm{s})$} & \multicolumn{2}{|c|}{$\mathrm{FEV}_{3}(\mathrm{~L})$} \\
\hline $\begin{array}{l}\text { House living area } \\
\text { per person }<20 \mathrm{~m}^{2}\end{array}$ & 0.033 & $\begin{array}{c}-0.010 \text { to } \\
0.076\end{array}$ & 0.026 & $\begin{array}{c}-0.011 \text { to } \\
0.063\end{array}$ & 0.058 & $\begin{array}{c}-0.051 \text { to } \\
0.167\end{array}$ & 0.002 & $\begin{array}{c}-0.070 \text { to } \\
0.074\end{array}$ & 0.034 & $\begin{array}{c}-0.010 \text { to } \\
0.077\end{array}$ \\
\hline Pet keeping & 0.049 & $\begin{array}{c}-0.009 \text { to } \\
0.107\end{array}$ & 0.038 & $\begin{array}{c}-0.011 \text { to } \\
0.087\end{array}$ & 0.102 & $\begin{array}{c}-0.043 \text { to } \\
0.247\end{array}$ & 0.034 & $\begin{array}{c}-0.063 \text { to } \\
0.130\end{array}$ & 0.049 & $\begin{array}{c}-0.008 \text { to } \\
0.107\end{array}$ \\
\hline $\begin{array}{l}\text { Window opening in } \\
\text { winter }<8 \mathrm{~h} \text { /day }\end{array}$ & -0.019 & $\begin{array}{c}-0.063 \text { to } \\
0.024\end{array}$ & -0.002 & $\begin{array}{c}-0.038 \text { to } \\
0.034\end{array}$ & 0.079 & $\begin{array}{c}-0.029 \text { to } \\
0.187\end{array}$ & 0.058 & $\begin{array}{c}-0.013 \text { to } \\
0.130\end{array}$ & -0.018 & $\begin{array}{c}-0.061 \text { to } \\
0.024\end{array}$ \\
\hline Share a bed & -0.006 & $\begin{array}{c}-0.051 \text { to } \\
0.038\end{array}$ & -0.007 & $\begin{array}{c}-0.044 \text { to } \\
0.030\end{array}$ & -0.007 & $\begin{array}{c}-0.118 \text { to } \\
0.104\end{array}$ & 0.005 & $\begin{array}{c}-0.069 \text { to } \\
0.079\end{array}$ & -0.007 & $\begin{array}{c}-0.051 \text { to } \\
0.037\end{array}$ \\
\hline
\end{tabular}

Adjusted for gender, age, height, respiratory diseases, premature birth, low birth weight and parental education level. FVC, forced vital

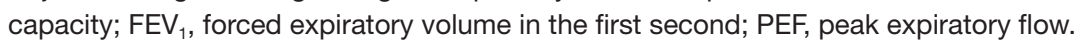

were frequently used had increased risk of lower $\mathrm{FEF}_{25-75}$ $(\beta=-0.13$ liter $)$ and PEF $(\beta=-0.17$ liter $)$ values, as shown in Table 6. Other variables (with $\mathrm{P}<0.15$ in the univariate analysis) did not show an effect on lung function.

\section{Diet, physical exercise and lung function $(n=771)$}

As for the frequency of fruit and vegetable consumption, we divided the subjects into three groups: 1-3 times a day, 1-6 times a week and 0-3 times a month. Regarding exercise grouping, we calculated the sum of children's weekly exercise time and divided them into two groups based on 1 hours of exercise per day. Table 7 presented the results of variance analysis between different food consumption groups and exercises time groups. After adjusting for gender, age, height, respiratory diseases, premature birth, low birth weight, parental education level and indoor environmental significant factors in previous analysis. We found that the higher the frequency of consumption of vegetable and dairy foods, the higher the $\mathrm{FVC}$ and $\mathrm{FEV}_{3}$ test values were. Children with higher frequency of fruits/vegetables consumption had higher $\mathrm{FVC}, \mathrm{FEV}_{1}$ and $\mathrm{FEV}_{3}$ test values. For example, children who ate vegetable "1-6 times a week" had an FVC value of about $36 \mathrm{~mL}$ higher than those who "never ate to three times a month". A cumulative exercise time of more than 1 hour per day were also positive with FVC ( $\beta=0.097$ liter) and $\mathrm{FEV}_{3}$ ( $\beta=0.097$ liter) test values, details were shown in Table 8 . We have also analyzed the relationship between die, exercise and respiratory diseases in 771 children, but found no significant associations (data not shown).

\section{Discussion}

There have been numerous studies on the effects of air pollution on children's respiratory health, while few reports on indoor environment where children spent the majority of their time. Similarly, the impact of lifestyle on children's lung function has not received enough attention. In view 
Table 7 Associations of lung function with diet and physical activity in children ${ }^{\mathrm{a}}$

\begin{tabular}{|c|c|c|c|c|c|c|c|c|c|c|c|}
\hline \multirow{2}{*}{ Variable } & \multirow{2}{*}{ Groups } & \multicolumn{2}{|c|}{ FVC } & \multicolumn{2}{|c|}{$\mathrm{FEV}_{1}$} & \multicolumn{2}{|c|}{ PEF } & \multicolumn{2}{|c|}{$\mathrm{FEF}_{25-75}$} & \multicolumn{2}{|c|}{$\mathrm{FEV}_{3}$} \\
\hline & & Value & $\mathrm{P}$ & Value & $\mathrm{P}$ & Value & $P$ & Value & $\mathrm{P}$ & Value & $\mathrm{P}$ \\
\hline \multicolumn{12}{|l|}{ Nutrition } \\
\hline \multirow[t]{2}{*}{$\begin{array}{l}\text { Vegetable } \\
\text { consumption }\end{array}$} & $\begin{array}{l}\text { Everyday } \\
(1-3 \text { times })^{b}\end{array}$ & $1.98 \pm 0.45$ & $0.002^{\star \star}$ & $1.82 \pm 0.40$ & $0.007^{\star \star}$ & $3.56 \pm 0.90$ & $0.001^{\star \star}$ & $2.28 \pm 0.63$ & 0.079 & $1.99 \pm 0.45$ & $0.002^{\star \star}$ \\
\hline & $\begin{array}{c}\text { Every month } \\
\text { (never-3 times/ }^{\text {month) }}{ }^{\mathrm{d}}\end{array}$ & $1.85 \pm 0.39$ & & $1.71 \pm 0.34$ & & $3.31 \pm 0.83$ & & $2.16 \pm 0.55$ & & $1.85 \pm 0.39$ & \\
\hline $\begin{array}{l}\text { Fruit con- } \\
\text { sumption }\end{array}$ & Everyday & $2.03 \pm 0.44$ & $0.000^{\star \star}$ & $1.86 \pm 0.39$ & $0.000^{\star \star}$ & $3.64 \pm 0.90$ & $0.005^{\star \star}$ & $2.33 \pm 0.63$ & $0.003^{\star \star}$ & $2.03 \pm 0.44$ & $0.000^{\star \star}$ \\
\hline \multirow{3}{*}{$\begin{array}{l}\text { Dairy products } \\
\text { consumption }\end{array}$} & Everyday & $2.00 \pm 0.44$ & $0.044^{\star}$ & $1.83 \pm 0.39$ & 0.123 & $3.56 \pm 0.88$ & 0.706 & $2.28 \pm 0.59$ & 0.633 & $2.00 \pm 0.43$ & $0.046^{*}$ \\
\hline & Every week & $1.94 \pm 0.41$ & & $1.80 \pm 0.38$ & & $3.58 \pm 0.63$ & & $2.28 \pm 0.63$ & & $1.94 \pm 0.41$ & \\
\hline & Every month & $1.91 \pm 0.41$ & & $1.76 \pm 0.35$ & & $3.51 \pm 0.88$ & & $2.23 \pm 0.61$ & & $1.91 \pm 0.41$ & \\
\hline \multicolumn{12}{|l|}{ Exercise } \\
\hline \multirow{2}{*}{$\begin{array}{l}\text { On campus } \\
+ \text { off campus } \\
\text { exercise }\end{array}$} & $<1$ hour/day & $1.95 \pm 0.42$ & $0.004^{\star \star}$ & $1.80 \pm 0.38$ & 0.054 & $3.55 \pm 0.90$ & 0.934 & $2.27 \pm 0.61$ & 0.881 & $1.95 \pm 0.42$ & $0.004^{\star *}$ \\
\hline & $\geq 1$ hour/day & $2.09 \pm 0.43$ & & $1.89 \pm 0.39$ & & $3.56 \pm 0.88$ & & $2.26 \pm 0.59$ & & $2.09 \pm 0.43$ & \\
\hline
\end{tabular}

Table 8 Multi-factor analysis of relationship between lifestyle and children's lung function

\begin{tabular}{|c|c|c|c|c|c|c|c|c|c|c|}
\hline Factors & \multicolumn{2}{|c|}{ FVC (L) } & \multicolumn{2}{|c|}{$\mathrm{FEV}_{1}(\mathrm{~L})$} & \multicolumn{2}{|c|}{ PEF (L/s) } & \multicolumn{2}{|c|}{$\mathrm{FEF}_{25-75}(\mathrm{~L} / \mathrm{s})$} & \multicolumn{2}{|c|}{$\mathrm{FEV}_{3}(\mathrm{~L})$} \\
\hline $\begin{array}{l}\text { Vegetable } \\
\text { consumption }\end{array}$ & 0.036 & $\begin{array}{c}0.007 \text { to } \\
0.066\end{array}$ & 0.024 & $\begin{array}{c}-0.001 \text { to } \\
0.049\end{array}$ & 0.049 & $\begin{array}{c}-0.025 \text { to } \\
0.123\end{array}$ & 0.026 & $\begin{array}{c}-0.023 \text { to } \\
0.075\end{array}$ & 0.036 & $\begin{array}{c}0.007 \text { to } \\
0.066\end{array}$ \\
\hline Fruit consumption & 0.043 & $\begin{array}{c}0.013 \text { to } \\
0.074\end{array}$ & 0.035 & $\begin{array}{c}0.009 \text { to } \\
0.061\end{array}$ & 0.068 & $\begin{array}{c}-0.010 \text { to } \\
0.145\end{array}$ & 0.050 & $\begin{array}{c}-0.001 \text { to } \\
0.101\end{array}$ & 0.043 & $\begin{array}{c}0.013 \text { to } \\
0.074\end{array}$ \\
\hline $\begin{array}{l}\text { On campus + off } \\
\text { campus exercise }\end{array}$ & 0.097 & $\begin{array}{c}0.028 \text { to } \\
0.165\end{array}$ & 0.046 & $\begin{array}{c}-0.011 \text { to } \\
0.104\end{array}$ & -0.048 & $\begin{array}{c}-0.219 \text { to } \\
0.123\end{array}$ & -0.046 & $\begin{array}{l}-0.159 \text { to } \\
0.066\end{array}$ & 0.097 & $\begin{array}{c}0.029 \text { to } \\
0.165\end{array}$ \\
\hline
\end{tabular}

Adjusted by sex, age, height, respiratory diseases, premature birth, low birth weight, parents' educational level and the variables that have significant effects in the analysis of indoor environment (dampness and mold, hygienic incense and mosquito coils, air conditioning time). FVC, forced vital capacity; FEV $_{1}$, forced expiratory volume in the first second; PEF, peak expiratory flow. 
of the changes in indoor environment, lifestyle and the rapid increase in the prevalence of respiratory diseases in children in China, it necessary to explore the impact of these two on children's respiratory health. Our study has used a combination of questionnaire and lung function test to explore the factors that may affect children's respiratory health in the indoor environment of primary school children in Chongqing, China. We also analyzed the effects of indoor environment and lifestyle on children's lung function. These results could provide a scientific basis for families to take preventive interventions against indoor pollution and children's eating and exercise habits.

Asthma was the most common chronic inflammatory disease of the respiratory tract in the world today and it was a complex polygenic inherited disease, which was often caused by the complex interaction of multiple genetic factors and environmental factors (16-18). Family and Gemini studies have shown that asthma has a familial aggregation and an obvious genetic predisposition, with a heritability of $60-80 \%(19-21)$. Our findings have confirmed that children with asthmatic parents were at a much higher risk of developing asthma. The same trend was also observed in the prevalence of bronchitis. Besides, more established factors, including premature birth, exclusive breastfeeding also have a significant impact on children's respiratory system in our study and have been analyzed and controlled in our data analysis.

\section{Indoor environment}

Room ventilation was reflected in our study by the time of window opening and air conditioning in summer. Our result showed the use of air conditioning for more than $8 \mathrm{~h} /$ day in summer was a risk factor for asthma, bronchitis and allergic rhinitis. The window opening for ventilation for less than $12 \mathrm{~h} /$ day was positively associated with allergic rhinitis. This is consistent with the findings of a previous study that the frequent window ventilation could reduce the risk of childhood asthma and allergic diseases significantly (22). Long-term use of air conditioning inevitably led to a reduction in window opening and ventilation time, which prevent the air exchange to some extent and exacerbate the accumulation of indoor pollutants including molds in the room. Ventilation also reduces the exposure to tobacco smoke to a certain extent if family members have smoking habits. The sharp rise in indoor particulate matter levels brought by open kitchens and Chinese-style cooking (23) may be a threat to children's respiratory health. Hence the ventilation of the kitchen was equally important.

We also found that indoor dampness and mold were a risk factor for childhood asthma, consistent with most previous studies. Although the climate of the previous study sites was different from Chongqing, the definitions of dampness and mold varied, including "window condensation" (24), "musty smell" (25), "mildew spots" (5,26), "wet bedding" (27), "water damage" (28), etc. What we ask in our study was "Did you find moist mold or smell mildew in your house? (including smelling mildew or observing mildew spots)". This was convenient to judge whether this phenomenon existed more comprehensively and objectively through vision and smell. We also found the harmful effects of dampness and mold on bronchitis and allergic rhinitis. The influence of humidity on indoor environment was mainly reflected in the following three aspects. Firstly, it led to the breeding of indoor mites. Secondly, it caused the rapid growth of indoor fungi and mold spores, which enhanced the exposure of mold and bacteria to the human body. Finally, humidity could cause the degradation of chemicals in furniture and synthetic materials to produce irritating and harmful gases (28). Although epidemiological evidences have suggested that microbial exposure play a key role in the causal relationship between dampness and childhood asthma, while the specific pathogenic factors have yet to be identified. Moreover, studies have shown that moderate exposure to certain microorganisms, especially in early life, could prevent the occurrence of asthma and other allergic diseases (29-31).

Our study also found that frequent use of hygienic incense and mosquito coils increased the risk of developing asthma and bronchitis in children. Indoor incense-burning, including mosquito coils or incense, was popular in Asian countries. However, little is known about the effects of indoor incense-burning on respiratory health. Studies have revealed the smoke characteristics of mosquito coils or incense, which including fine and ultrafine particles, PAHs, VOCs and aldehydes, with high irritation and suspected carcinogenic effects. Burning one mosquito coil would release PM2.5 with the same mass as burning 75-137 cigarettes and release formaldehyde with the same concentration as burning 51 cigarettes (32). A cross-sectional study in Hong Kong (33) did not find the association between exposure to incense burning and respiratory symptoms like asthma and allergic rhinitis. While Wang (34) found that incense burning was a risk factor for asthma based on 3,764 schoolchildren in Taiwan, this was consistent with our study that the risk of asthma increased by 2.58 times and bronchitis by 1.42 times 
in households with frequently used hygienic incense and mosquito coils. However, due to the wide variety and different components of incense and the lack of relevant population studies, this correlation still needs further discussion.

Only frequent use of air fresheners was found to be associated with reduced $\mathrm{FEF}_{25-75}$ and $\mathrm{FEV}_{3}$ values in children. A study conducted in American adults found that 1,4-dichlorobenzene (1,4-DCB) was associated with reduced pulmonary function after adjusting for smoking. 1,4-DCB was commonly found in air fresheners, toilet bowl deodorants, and mothballs (35). Air fresheners have also been found to increase lung irritation and toxic effects on mice in acute toxicity experiments on mice (36). There are numerous types of air fresheners, which traditionally consist of diethyl ether and aromatic flavor ingredients. Besides, propane, butane, dimethyl ether and other ingredients are added to high-pressure canned products and these ingredients could impair children's lung function. The use of air fresheners does not improve indoor air quality. Instead, it could exacerbate indoor pollution.

It is worth mentioning that, our study found that children whose mothers had higher education attainment were more likely to develop asthma, bronchitis and allergic rhinitis. The reasons may come from two aspects. For one thing, mother of a lower education level may have had fewer opportunities for children to receive health care and thus their children might have missed the chance to be diagnosed with respiratory diseases (37). For another, mothers with a higher education level often have better family economic conditions. Children in such families were less likely to develop early microbial infections, and hence may be more susceptible to allergic diseases (38).

\section{Diet and exercise}

Nutritional factors play an important role in respiratory health by influencing the immune system. Previous studies exploring the relationship between diet and respiratory health have suggested that the lack of antioxidants and minerals in the diet and the imbalance of essential fatty acid intake were potential risk factors for asthma and other respiratory diseases (39-42). However, few have examined the impact of exercise and healthy diet on children's lung function $(10,11)$. Our results indicated that intake of vegetables, fruits and dairy products were associated with better lung function ( $\mathrm{FVC}, \mathrm{FEV}_{1}, \mathrm{FEV}_{3}$ ) in children. This is consistent with the results from Romieu et al. (11), which reported that the consumption of vegetable and fruit intake was positively related to forced expiratory volume in one second $\left(\mathrm{FEV}_{1}\right)$ and FVC. Gilliland et al. (10) pointed out that low intakes of vitamin $\mathrm{C}$ was related to boys' $\mathrm{FVC}$ and $\mathrm{FEV}_{1}$ deficiency. Physical exercise also can improve cardiopulmonary function effectively, while most of the previous studies focused on adults or athletes and rarely examined the relationship in children. A study conducted in Korean suggested that aerobic exercise combined with strength training could improve children's lung function. Consistently, we found that exercise for more than 1 hour a day was positively associated with the test values of $\mathrm{FVC}$ and $\mathrm{FEV}_{3}$ in the target children.

This study filled the gap in the research of the relationship between home indoor environment and respiratory diseases (bronchitis, allergic rhinitis) other than asthma. In addition, few studies have investigated the relationship between lung function with indoor environment and lifestyle. However, our findings should be interpreted with the following study limitations in mind. Firstly, cross-sectional design means that it was difficult to establish a causal relationship between the exposure and outcome variables. Secondly, exposure to indoor risk factors was ascertained by questionnaire and we did not conduct exposure assessment in the home of the children due to resource constraints. Thirdly, the environment of school classroom was not covered in the questionnaire. In addition, although the results of this study were basically similar to those of other studies conducted in Chongqing in terms of the prevalence of respiratory diseases and the indoor environment, this may not be generalized to all children in the city due to convenience sampling used in the current study.

\section{Conclusions}

In school children living in a Chongqing with a humid climate, we confirmed several previously established risk factors of respiratory health, including heredity, preterm birth and breastfeeding. We further identified the following indoor environment risk factors related to children's respiratory health, including poor ventilation, dampness and mold, frequently burning of hygienic incense and mosquito coils, and home use of air fresheners. In addition, we found that consumption of vegetables, fruits and dairy products and exercise for more than 1 hour per day were associated with improved lung function, respectively.

\section{Acknowledgments}

We would like to thank the students and their parents 
for their participation. We are grateful to the leaders and teachers of the two primary schools for their kind assistance with recruitment and sample collection. We would like to thank professors Xiaoli Duan and Suzhen Cao and graduate student Sai Li from Beijing University of Science and Technology for their comments on the paper. Funding: None.

\section{Footnote}

Provenance and Peer Review: This article was commissioned by the Guest Editors (Junfeng Zhang, Howard Kipen and Haidong Kan) for the series "Children's Respiratory Health and Air Quality" published in Fournal of Thoracic Disease. This article has undergone external peer review.

Conflicts of Interest: All authors have completed the ICMJE uniform disclosure form (available at http://dx.doi. org/10.21037/jtd.2020.03.102). The series “Children's Respiratory Health and Air Quality” was commissioned by the editorial office without any funding or sponsorship. JFZ served as the unpaid Guest Editor of the series and serves as an unpaid editorial board member of Fournal of Thoracic Disease. The other authors have no other conflicts of interest to declare.

Ethical Statement: The authors are accountable for all aspects of the work in ensuring that questions related to the accuracy or integrity of any part of the work are appropriately investigated and resolved. The study protocol was approved by the Chongqing Medical University Ethics Committee (No. 2017005) and Duke Kunshan University IRB (No. FWA00021580), respectively. Informed consent was obtained from both participating children and their parents or guardians.

Open Access Statement: This is an Open Access article distributed in accordance with the Creative Commons Attribution-NonCommercial-NoDerivs 4.0 International License (CC BY-NC-ND 4.0), which permits the noncommercial replication and distribution of the article with the strict proviso that no changes or edits are made and the original work is properly cited (including links to both the formal publication through the relevant DOI and the license). See: https://creativecommons.org/licenses/by-nc-nd/4.0/.

\section{References}

1. Zhang YP. Ten cities cross-sectional questionnaire survey of children asthma and other allergies in China. Chinese Science Bulletin 2013;58:4182-9.

2. Sun Y, Sundell J. Life style and home environment are associated with racial disparities of asthma and allergy in Northeast Texas children. Sci Total Environ 2011;409:4229-34.

3. Takaoka M, Suzuki K, Norbäck D. Current asthma, respiratory symptoms and airway infections among students in relation to the school and home environment in Japan. J Asthma 2017;54:652-61.

4. Tin Tin S, Woodward A, Saraf R, et al. Internal living environment and respiratory disease in children: findings from the Growing Up in New Zealand longitudinal child cohort study. Environ Health 2016;15:120.

5. Lu Y, Lin S, Lawrence WR, et al. Evidence from SINPHONIE project: Impact of home environmental exposures on respiratory health among school-age children in Romania. Sci Total Environ 2018;621:75-84.

6. Madureira J, Paciência I, Cavaleiro-Rufo J, et al. Indoor pollutant exposure among children with and without asthma in Porto, Portugal, during the cold season. Environ Sci Pollut Res Int 2016;23:20539-52.

7. Zhang D. Clinical research progress of respiratory diseases in children. J Clin Med 2019;6:193.

8. Guo YC, Yu KH. Review on fitness health study of Chinese Students from year of 1985 2015. Zhejiang Sport Science 2016;38:62-8.

9. Lampe JW. Health effects of vegetables and fruit: assessing mechanisms of action in human experimental studies. Am J Clin Nutr 1999;70:475S-490S.

10. Gilliland FD, Berhane KT, Li YF. Children's lung function and antioxidant vitamin, fruit, juice, and vegetable intake. Am J Epidemiol 2003;158:576-84.

11. Romieu I, Barraza-Villarreal A, Escamilla-Núñez C, et al. Dietary intake, lung function and airway inflammation in Mexico City school children exposed to air pollutants. Respir Res 2009;10:122.

12. Nystad W, Samuelsen SO, Nafstad P, et al. Association between level of physical activity and lung function among Norwegian men and women: the HUNT study. Int J Tuberc Lung Dis 2006;10:1399-405.

13. Pelkonen M, Notkola IL, Lakka T, et al. Delaying decline in pulmonary function with physical activity: a 25 -year follow-up. Am J Respir Crit Care Med 2003;168:494-9.

14. Pearce N, Weiland S, Keil U, et al. Self-reported prevalence of asthma symptoms in children in Australia, England, Germany and New Zealand: an international comparison using the ISAAC protocol. Eur Respir J 1993;6:1455-61.

15. Worldwide variation in prevalence of symptoms of 
asthma, allergic rhinoconjunctivitis, and atopic eczema: ISAAC. The International Study of Asthma and Allergies in Childhood (ISAAC) Steering Committee. Lancet 1998;351:1225-32.

16. Vercelli D. Discovering susceptibility genes for asthma and allergy. Nat Rev Immunol 2008;8:169-82.

17. Lee JU, Kim JD, Park CS. Gene-Environment Interactions in Asthma: Genetic and Epigenetic Effects. Yonsei Med J 2015;56:877-86.

18. Rigoli L, Briuglia S, Caimmi S, et al. Gene-environment interaction in childhood asthma. Int J Immunopathol Pharmacol 2011;24:41-7.

19. Skadhauge LR, Christensen K, Kyvik KO, et al. Genetic and environmental influence on asthma: a populationbased study of 11,688 Danish twin pairs. Eur Respir J 1999;13:8-14.

20. Palmer LJ, Burton PR, James AL, et al. Familial aggregation and heritability of asthma-associated quantitative traits in a population-based sample of nuclear families. Eur J Hum Genet 2000;8:853-60.

21. $\mathrm{Wu} \mathrm{XH}$. Study on the polymorphisms of asthma related genes. Huazhong University of Science and Technology, 2010.

22. Wang JH. Home ventilation and its association with asthma and allergic among preschool children in Chongqing. Chongqing University, 2015.

23. Liao CM, Chen SC, Chen JW, et al. Contributions of Chinese-style cooking and incense burning to personal exposure and residential PM concentrations in Taiwan region. Sci Total Environ, 2006;358:72-84.

24. Bornehag CG, Sundell J, Hagerhed-Engman L, et al. 'Dampness' at home and its association with airway, nose, and skin symptoms among 10,851 preschool children in Sweden: a cross-sectional study. Indoor Air 2005;15 Suppl 10:48-55.

25. Liu YL. The relationship study of home indoor dampness and health of children in Chongqing. Chongqing: Chongqing University, 2013.

26. Karvonen AM, Hyvärinen A, Roponen M, et al. Confirmed moisture damage at home, respiratory symptoms and atopy in early life: a birth-cohort study. Pediatrics 2009;124:e329-38.

27. Wang H, Li B, Yang Q, et al. Dampness in dwellings and its association with asthma and allergies among children in Chongqing: A cross-sectional study. Chin Sci Bull 2013;58:2584-91.

28. $\mathrm{Hu}$ Y. Research on the association between home dampness and asthma related symptoms among pre-school children of Shanghai. Shanghai: University of Shanghai for Science and Technology, 2012.

29. Liu AH, Leung DY. Renaissance of the hygiene hypothesis. J Allergy Clin Immunol 2006;117:1063-6.

30. Douwes J, Le Gros G, Gibson P, et al. Can bacterial endotoxin exposure reverse atopy and atopic disease? J Allergy Clin Immunol 2004;114:1051-4.

31. Mendell MJ, Mirer AG, Cheung K, et al. Respiratory and allergic health effects of dampness, mold, and dampnessrelated agents: a review of the epidemiologic evidence. Environ Health Perspect 2011;119:748-56.

32. Liu W, Zhang J, Hashim JH, et al. Mosquito coil emissions and health implications. Environ Health Perspect 2003;111:1454-60.

33. Koo LC, Ho JHC, Tominaga S, et al. Is Chinese Incense Smoke Hazardous to Respiratory Health? Indoor Built Environ 1995;4:334-43.

34. Wang IJ, Tsai CH, Chen CH, et al. Glutathione S-transferase, incense burning and asthma in children. Eur Respir J 2011;37:1371-7.

35. Elliott L, Longnecker MP, Kissling GE, et al. Volatile organic compounds and pulmonary function in the Third National Health and Nutrition Examination Survey, 19881994. Environ Health Perspect 2006;114:1210-4.

36. Anderson RC, Anderson JH. Toxic effects of air freshener emissions. Arch Environ Health 1997;52:433-41.

37. Lee YL, Lin YC, Hsiue TR, et al. Indoor and Outdoor Environmental Exposures, Parental Atopy, and PhysicianDiagnosed Asthma in Taiwanese Schoolchildren. Pediatrics 2003;112:e389.

38. Illi S, von Mutius E, Lau S, et al. Early childhood infectious diseases and the development of asthma up to school age: a birth cohort study. BMJ 2001;322:390-5.

39. Antova T, Pattenden S, Nikiforov B, et al. Nutrition and respiratory health in children in six Central and Eastern European countries. Thorax 2003;58:231-6.

40. Forastiere F, Pistelli R, Sestini P, et al. Consumption of fresh fruit rich in vitamin $\mathrm{C}$ and wheezing symptoms in children. SIDRIA Collaborative Group, Italy. Thorax 2000;55:283-8.

41. Fawzi W, Herrera MG, Nestel P. Tomato intake in relation to mortality and morbidity among Sudanese children. J Nutr 2000;130:2537-42.

42. Takemura Y, Sakurai Y, Honjo S, et al. The relationship between fish intake and the prevalence of asthma: the Tokorozawa childhood asthma and pollinosis study. Prev Med 2002;34:221-5.

Cite this article as: Li W, Liu Q, Chen Y, Yang B, Huang X, Li Y, Zhang JJ. Effects of indoor environment and lifestyle on respiratory health of children in Chongqing, China. J Thorac Dis 2020;12(10):6327-6341. doi: 10.21037/jtd.2020.03.102 